\title{
Nordisk Forening for Psykiatrisk Epidemiologi (Nordic Association for Psychiatric Epidemiology - NAPE)
}

\author{
Povl Munk-Jørgensen, MD, Professor, DrMed \\ Department of Psychiatric Demography, Aarhus University, DK 8240 Risskov, Denmark
}

\begin{abstract}
ENGLISH ABSTRACT
Nordic Association for Psychiatric Epidemiology was established in 1997 as a successor to the Nordisk Planeringsgrupp för psykiatrisk hälso- och sjukvårdsforskning (Nordic planning-group for Psychiatric Health Service Research). The major purpose of the association is to promote research within psychiatric epidemiology in the 5 Nordic countries (Denmark, Finland, Iceland, Norway, Sweden) with the specific aim to recruit and supervise younger researchers within psychiatric epidemiology. Among the organization's purposes are also to initiate inter-Nordic psychiatric epidemiological multicenter research and organize Nordic research courses on the highest possible level, together with creation of inter-Nordic contact networks. Over the past 25 years the association (and its predecessor) has organized several research courses and 4 inter-Nordic multicenter studies within the areas: Mental disorders in primary care, Sectorized psychiatry, Coercion in psychiatry, and Schizophrenic patients' need for treatment. The outcome has been several $\mathrm{PhD}$-theses and a long row of publications.
\end{abstract}

For further information, the present (August 2002) Norwegian representative in the board is Eystein Stordal, e-mail: eystein.stordal@hnt.no

\section{INDLEDNING}

Foreningen, der er en videnskabelig organisation, har til formål, at:

- fremme forskning inden for psykiatrisk epidemiologi i de nordiske lande, herunder især at rekruttere og vejlede yngre forskere inden for området,

- fremme samarbejdet mellem de nordiske lande inden for psykiatrisk epidemiologisk forskning,

- arbejde for oprettelse af lærestole i psykiatrisk epidemiologi i de nordiske lande,

- stimulere nordiske psykiatrisk epidemiologiske forskere til øget internationalt samarbejde,

- stimulere til at resultater fra psykiatrisk epidemiologisk forskning anvendes i de nordiske lande.

Især de to første formål er af meget stor betydning.

For det første er det selvindlysende, at uden forskere bliver der ikke udført forskning. Der har været en tendens til stagnation inden for den psykiatriske forskning $i$ de nordiske lande, mere udtalt $i$ nogle end $i$ andre. Aktivitetsniveauet er faldet. Eksempelvis har en netop publiceret undersøgelse i Danmark vist, at reservelæger i psykiatrien hører til blandt de absolut mindst forskende inden for de medicinske specialer. Det er derfor ikke nok med planer, strategier, udvalg, råd, nævn og hensigtserklæringer. Den enkelte forsker, in casu den psykiatriske epidemiologiske forsker, må kontakte yngre kolleger, som viser interesse og rekruttere dem til forskningsarbejde, vejlede dem, supervisere dem, sætte dem i gang og i det hele taget inkludere dem $i$ arbejdet med entusiasme og imødekommenhed.
Jo yngre kolleger, jo bedre, meget gerne prægraduate. Problemstillingen gælder ikke blot læger men alle faggrupper, især de akademiske inden for psykiatrien. Uden forskning dør et fag bort.

For det andet er det vigtigt, at vi samarbejder inden for de nordiske lande. Hver især er vi så små, at vi vil få vanskeligt ved at slå igennem i konkurrencen på den internationale scene. De epidemiologiske miljøer, der eksisterer i de fem nordiske lande, vil alle kunne få udtalt gavn af at samarbejde med hinanden. Samlet repræsenterer vi en befolkning på op imod 25 mio. mennesker. I disse år, hvor ressourcerne bliver mindre, hvor konkurrencen om ressourcerne bliver hårdere, og hvor kravet om effektiv ressourceudnyttelse stiger, er en opgavedeling mellem centre i Norden absolut påkrævet.

\section{LIDT OM NAPES HISTORIE}

Nordic Association for Psychiatric Epidemiology (NAPE) er efterfølgeren til Nordisk Planeringsgrupp för psykiatrisk hälso- och sjukvårdsforskning, der blev stiftet i midten af 1980 'erne, som en aflægger af Nordisk Planeringsgrupp för hälso- och sjukvårdsforskning. Initiativtager var Ville Lehtinen fra Turku og Claes-Göran Westrin fra Uppsala. Allerede fra start havde hvert af de nordiske lande 1-3 repræsentanter i denne gruppe. Arbejdet $\mathrm{i}$ gruppen foregik på et ikke officielt grundlag. Gruppen var ikke officielt nedsat og blev ikke finansieret statsligt eller på anden måde offentligt. Dog lykkedes det ved adskillige lejligheder at tilvejebringe midler fra især offentlige nordiske 
fonde. Gruppen udviklede derimod, især ved ClaesGöran Westrins og Ville Lehtinens initiativ og idérigdom, en stor ekspertise $\mathrm{i}$ at mødes ved andre nordiske og internationale kongresser, når "lejlighed bød sig". Gruppen havde dengang ingen formålsparagraf og intet nedskrevet regelsæt, arbejdet blev drevet af entusiasme og gensidig tillid og respekt.

Først i 1997 fandt man anledning til at gøre gruppen mere officiel, hvorfor man ved et møde i Roskilde i Danmark i efteråret 1997 stiftede NAPE: Nordic Association for Psychiatric Epidemiology (Nordisk Forening for Psykiatrisk Epidemiologi). Denne gruppe fungerer nu efter godkendt regelsæt og det daglige koordinerende arbejde udføres af en bestyrelse. Der afholdes én gang årligt et 2-3 dages årsmøde, hvor man samtidig afholder den årlige generalforsamling.

\section{LIDT OM ARBEJDET}

Tilbage i midten af 1980 'erne, da foreningen stadigvæk fungerede uofficielt under navnet Nordisk Planeringsgrupp för psykiatrisk hälso- och sjukvårdsforskning arbejdede man især for at etablere inter-nordiske multicenterprojekter og afholde forskerkurser, altsammen for at fremme den psykiatrisk epidemiologiske forskning, kvantitativt og kvalitativt, etablere internordiske samarbejdsnetværk og kontakter samt, hvilket ikke kan understreges ofte nok, rekruttere yngre forskere til den psykiatrisk epidemiologiske forskning.

Gruppen gennemførte 5 forskerkurser, finansieret ved midler bevilliget af NorFA. Kurserne var 1-uge varende for ca. 25 forskere, især yngre, men med gennemgående deltagelse af seniorer kolleger. Kurserne blev afholdt:

- 1987 i Uppsala

- 1989 på Lofoten

- 1991 i Turku

- 1994 i København

- 1996 i Skanderborg.

Kurserne var en vekselvirkning mellem katedral undervisning ved nordiske og internationale lærere, workshops og, som et højt prioriteret tema, gruppediskussioner med formål at designe nordiske multicenterundersøgelser inden for kursernes overordnede temaer.

På denne vis lykkedes det at etablere 4 nordiske forskergrupper, der alle fortsat er aktive:

- Psykisk sygdom i almen praksis

- Sektoriseret psykiatri

- Tvang i psykiatrien

- Skizofrene patienters behov for behandling.

Produktiviteten i grupperne har været meget høj. Mange internationale og nordiske videnskabelige publikationer har været resultatet, ligesom adskillige ph.d.afhandlinger, for ikke at tale om den megen forskeruddannelse et stort antal kolleger har gennemgået ved at deltage i kurserne og i praktisk forskningsarbejde.
Principperne for forskningsprojekterne har været at opretholde en meget lav grad af central styring for $\mathrm{i}$ stedet at fokusere på decentral kreativitet og udvikling af projekterne. Af samme grund eksisterer der ikke i dag nogen samlet opgørelse over out-come fra de 4 forskningsprojekter.

\section{OM ÅRSMøDERNE}

Årsmøderne har som faste programpunkter en international, inviteret foredragsholder. Dette foredrag publiceres hvert år i januar i Acta Psychiatrica Scandinavica. Herforuden er der mange orale præsentationer, heraf 1 awardforedrag samt posterpræsentationer med uddeling af posterawards.

Årsmødet fokuserer på at præsentere såvel foreliggende resultater som igangværende projekter og projekter under planlægning. Jo tidligere $\mathrm{i}$ et forløb man får mulighed for at diskutere et projekt med kolleger, jo højere bliver kvaliteten af projektet, når det først sættes i gang. En væsentlig hensigt med årsmøderne er, at kolleger møder hinanden på tværs af landegrænser, på tværs af fag, på tværs af alder og generation, på tværs af kompetence og ekspertise, og at netværk og samarbejdsrelationer etableres.

\section{OM FREMTIDEN}

Udgangspunktet for etableringen af Nordisk Forening for Psykiatrisk Epidemiologi var den deskriptive epidemiologi appliceret på sundhedstjenesteforskning, hvilket fremgik af navnet: Psykiatrisk hälso- och sjukvårdsforskning.

I de seneste 15-20 år har epidemiologien, og dermed også den psykiatriske epidemiologi, gennemgået en rivende udvikling, således, at den nu er metode for en lang række områder inden for den psykiatriske forskning:

- Populationsundersøgelser

- Sundhedstjenesteforskning

- Behandlingsforskning

- Socialpsykiatrisk forskning

- Genetisk epidemiologisk forskning

- Klinisk forløbsforskning

- Sundhedsøkonomisk forskning

- m.m.

Hvis foreningen skal have en berettigelse påhviler der bestyrelsen en stor opgave $\mathrm{i}$ at inddrage disse mange områder i sin funktion, i praksis fx ved:

- At identificere og supportere de enheder og forskningscentre, der arbejder inden for de enkelte områder, nævnt ovenfor.

- Tilbyde vejledning enten ved egne medlemmer eller ved at identificere vejledere og formidle kontakt til disse gennem foreningens netværk.

- Initiere nordiske multicenterprojekter inden for relevante områder. 
- Sikre rekruttering, forskningsigangsættelse og vejledning af yngre forskningskolleger.

- Understøtte etablering og vedligeholdelse af nordiske kontakt netværk og specielt sikre kontakt mellem juniorer og seniorer forskere.

- Tage initiativ til og organisere og gennemføre forskerkurser på højt videnskabeligt niveau.

- Bidrage til at præge udviklingen inden for de forskellige grene af psykiatrisk epidemiologi, meget

- og i det hele taget tænke originalt, utraditionelt, entusiastisk og engageret. gerne ved at tage direkte initiativer, bidrage til at koordinere og samle interesserede og engagerede forskerkolleger i hele Norden.

- Arbejde for at organisationen bliver medlemmernes organisation, hvilket vil sige at arbejde for en down upmodel frem for top downmodel, vel vidende at den første model er betydelig mere arbejdskrævende for en organisation end den sidste. 